\title{
Advancing global medical education in otolaryngology through hands-on skills training and simulation-based learning
}

\author{
Angela Cao ${ }^{1}$, Jeremy Feintuch ${ }^{1}$, Joshua Feintuch ${ }^{1}$, Luan Tran ${ }^{2,3}$, Brent Senior ${ }^{4}$, \\ Christina J Yang ${ }^{1}$
}

\begin{abstract}
${ }^{1}$ Department of Otorhinolaryngology-Head and Neck Surgery, Albert Einstein School of Medicine/Montefiore Medical Center, Bronx, New York, New York, USA

${ }^{2}$ Department of Otolaryngology-Head and Neck Surgery, Pham Ngoc Thach University of Medicine, Ho Chi Minh City, Vietnam ${ }^{3}$ Ear, Nose, and Throat Hospital of Ho Chi Minh City, Ho Chi Minh City, Vietnam

${ }^{4}$ Department of Otolaryngology-Head and Neck Surgery, University of North Carolina School of Medicine, Chapel Hill, North Carolina, USA
\end{abstract}

\begin{abstract}
G
\end{abstract} lobal health is moving toward a focus on building strong and sustainable health systems in developing countries [1]. For global surgery, this means moving beyond short-term mission trips that solely deliver care and rather, towards education - teaching techniques, guiding post-operative care, and building surgical capacity of the local health care community. Global surgery collaborations should support surgical workforce development, education, and training of local surgeons in a manner that allows a bidirectional exchange of knowledge and resources [2], thereby developing the local capacity for sustainable surgical care.

In response to this call, one aspect of global surgery has shifted to in-country training of local surgeons [3]. Some global surgery groups have only recently started to formally incorporate these goals in their trips overseas. Fuller et al [3] employed a surgical curriculum in Ecuador focused on short lecture didactics, live surgery participation, and a surgical simulator to teach skills on various aspects of rhinoseptoplasty surgery. Vyas et al [4] report a curriculum based on virtual augmented reality to remotely proctor and guide surgical training of cleft-lip surgery for plastic surgeons in Peru. And Parham et al [5] designed a virtual reality surgical simulator to help novice surgeons perform radical abdominal hysterectomy surgery procedure in Zambia. We applaud these worthwhile endeavors, but also advocate the need for low-cost, easily assembled surgical simulators, especially in resource poor areas.

\section{Surgeons interested in global health should} move beyond mission trips that focus on short term care, and rather should address strategies that focus on establishing longterm relationships with sustainable impact and capacity building.

Surgical simulation has become an integral educational tool in United States surgical training programs. It has been widely established as a valuable and effective means of training surgeons prior to entering the operating room [6]. The American Academy of Otolaryngology-Head and Neck Surgery Foundation established the Otolaryngology Surgical Simulation Task Force in 2011, recognizing the importance of this tool in training surgical trainees [7]. The global surgical community recognizes its importance too and parts of the developing world are yearning for these tools. A recent review by Hasan et al [8] from Aga Khan University in Pakistan 


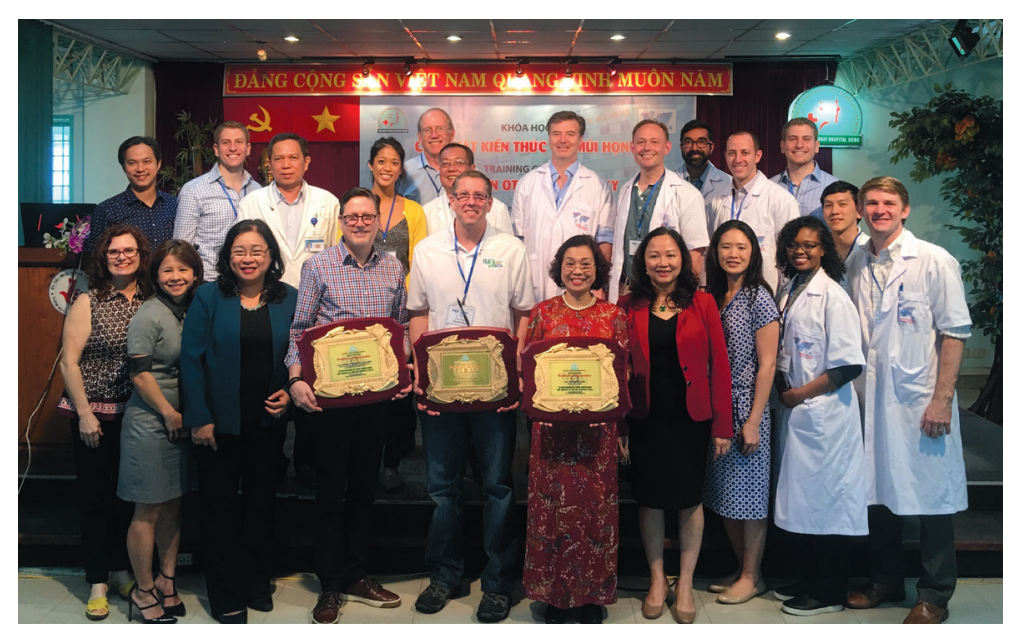

Photo: From the collection of Angela Cao, used with permission.

describes the need of simulation in surgical education in developing countries. While low- and middle-income countries (LMIC) institutions may be restricted to an apprenticeship model of learning surgery in a "see one, do one" manner due to either financial or resource constraints, we successfully introduced a low-cost simulation task trainer to develop sinus surgery skills that participants can directly learn and practice with hand-on training outside of the operating room.

In recent years, our otolaryngology departments at Albert Einstein College of Medicine and the University of North Carolina at Chapel Hill have participated with Resource Exchange International (REI) Vietnam, a non-profit organization that has been working in Vietnam for over 25 years to build medical and health care capacity. These trips have been supported, in part, by the Vietnam Ministry of Health and led by American otolaryngologists since 1992, focusing on collaborations with medical universities with otolaryngology training programs in Hanoi and Ho Chi Minh City (HCMC). These institutions provide undergraduate and postgraduate training for the entire country. In collaboration with the Vietnamese Ministry of Health and Vietnamese physicians, our years of exchange work to accomplish the organization's mission to "build people to build a nation."

During one of our recent REI Vietnam trips, we traveled to HCMC with a team of 20 volunteers, made up of American otolaryngology attendings, residents, and medical students. Our visit began with a 2-day course called "Update in Otolaryngology," hosted by Pham Ngoc Thach University of Medicine and ENT Hospital of HCMC with lectures given by our group. This course is an annual highlight and attended by around 200 health care professionals from throughout the region. Through years of established partnership with our Vietnamese otolaryngology colleagues, an educational gap in endoscopic sinus surgery was identified among trainees with regard to dexterity and technical handling of instrumentation that could be addressed through ENT simulation-based training.

For our teaching objectives, we brought a task trainer to simulate endoscopic sinus surgery using a gelatin-based model established by Malekzadeh et al [9]. Developed to teach junior otolaryngology residents basic endoscopy and sinus surgery skills, we replicated this model with 11 Vietnamese otolaryngology residents and 1 Vietnam-

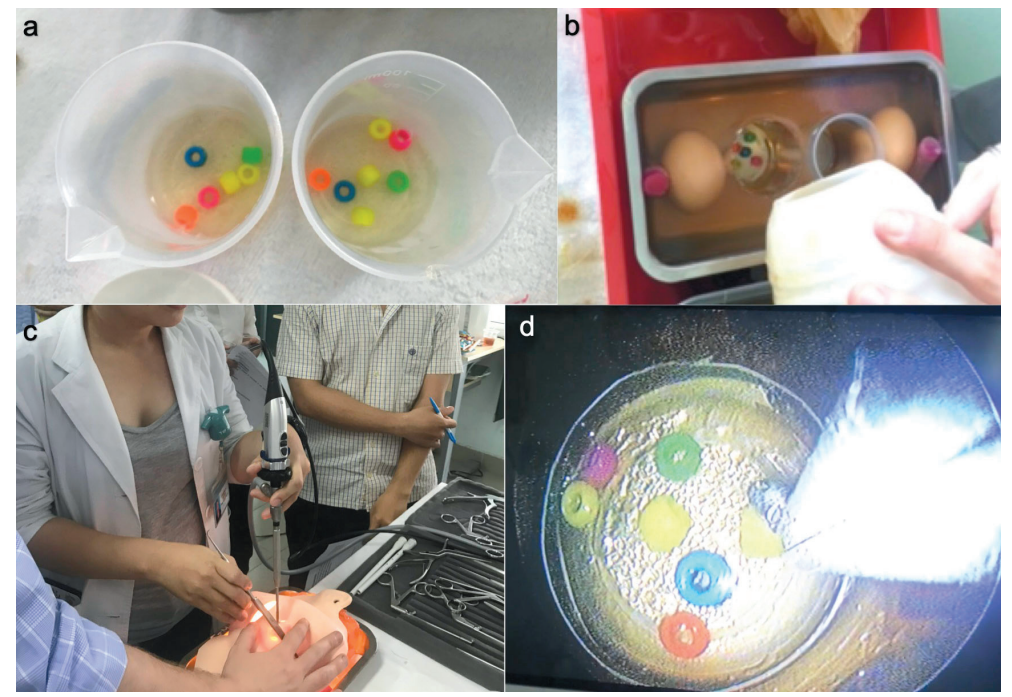

Figure 1. Assembly of the gelatin-based sinus surgery simulator. Panel A. Small discs of beads suspended in gelatin are prepared that were transferred into the simulator for the bead removal task. Panel B. Gelatin-based sinus surgery task trainer cooling in a baking pan. Eggs were suspended in gelatin to represent the maxillary sinus. Licorice candies were used laterally to position the eggs while the gelatin was cooling. Panel C. Sinus trask trainer with cardiopulmonary resuscitation (CPR) face mask in place. Panel D. Endoscopic view of bead removal task. ese otolaryngology attending. For less than US\$5 dollars, we easily constructed and reproduced the task trainer on-site purchasing gelatin, beads, eggs, and licorice candy at local street markets in HCMC (Figure 1). The task trainer was used to simulate endoscopic sinus surgery tasks including uncinectomy, maxillary antrostomy, suture removal, and endoscopic injections. Tasks were completed using the model, a 0-degree endoscope, video tower, and standard sinus instruments.

After performing sinus endoscopy and the described tasks, participants provided feedback by completing an 18-question evaluation of the sinus trainer. This included questions used by Steehler et al [6] in assessing the validity of the sinus surgery task trainer developed by Malekzadeh [9]. A series of statements translated into both English and Vietnamese asked participants to rate the sinus model on its ability to develop general endoscopy skills and its ability to teach specific tasks and instrumentation using a 5-point Likert scale (strongly disagree to strongly agree). Results are shown in Table 1. 
Table 1. Participant survey with 5-point Likert-type scale response

\begin{tabular}{|c|c|c|c|c|c|c|}
\hline \multirow[t]{2}{*}{ STATEMENTS AND LIKERT-TYPE SCALE RESPONSES } & \multicolumn{5}{|c|}{ PERCENTAGE RESPONDING (No.) } & \multirow[t]{2}{*}{ MEAN \pm SD } \\
\hline & $\begin{array}{l}\text { Strongly } \\
\text { Disagree } \\
\text { (Hoàn } \\
\text { toàn } \\
\text { không } \\
\text { đồng ý }\end{array}$ & $\begin{array}{l}\text { Disagree } \\
\text { (Không } \\
\text { đồng ý) }\end{array}$ & $\begin{array}{l}\text { Neutral } \\
\text { (Không ý } \\
\text { kiến) }\end{array}$ & $\begin{array}{l}\text { Agree } \\
\text { (Đồng ý) }\end{array}$ & $\begin{array}{l}\text { Strongly } \\
\text { Agree } \\
\text { (Hoàn } \\
\text { toàn } \\
\text { đồng ý) }\end{array}$ & \\
\hline $\begin{array}{l}\text { This model helps to develop camera skills needed for FESS (Mô hình này giúp phát } \\
\text { triển kỹ năng sử dụng camera cần thiết cho phẫu thuật nội soi chức năng xoang) }\end{array}$ & 0 & 0 & 0 & $25(3)$ & $75(9)$ & $4.8 \pm 0.45$ \\
\hline $\begin{array}{l}\text { This model helps to develop hand-eye coordination needed for FESS (Mô hình } \\
\text { này giúp phát triển khả năng phối hợp mắt - tay cần thiết cho phẫu thuật nội soi } \\
\text { chức năng xoang) }\end{array}$ & 0 & 0 & 0 & $17(2)$ & $83(10)$ & $4.8 \pm 0.39$ \\
\hline $\begin{array}{l}\text { This model helps to develop skills needed for nasal endoscopy (Mô hình này giúp } \\
\text { phát triển kỹ năng cần thiết cho nội soi mũi) }\end{array}$ & 0 & 0 & 0 & $33(4)$ & $58(8)$ & $4.7 \pm 0.49$ \\
\hline $\begin{array}{l}\text { This model helps to develop skills needed for frontoethmoid recess exploration (Mô } \\
\text { hình này giúp phát triển kỹ năng cần thiết để khảo sát ngách sàng trán) }\end{array}$ & 0 & $8(1)$ & $42(5)$ & $17(2)$ & $33(4)$ & $3.8 \pm 1.06$ \\
\hline $\begin{array}{l}\text { The frontoethmoid recess task is a valuable training exercise (Bài tập về ngách sàng } \\
\text { trán là huấn luyện có giá trị) }\end{array}$ & 0 & 0 & $17(2)$ & $58(7)$ & $33(3)$ & $4.1 \pm 0.69$ \\
\hline $\begin{array}{l}\text { This model helps to develop fundamental use of straight and } 45 \text {-degree Blakesley } \\
\text { (Mô hình này giúp phát triển kỹ năng sử dụng cơ bản kềm Blakesley thẳng và } \\
\text { Blakesley } 45 \text { độ) }\end{array}$ & 0 & 0 & 0 & $33(4)$ & $67(8)$ & $4.7 \pm 0.49$ \\
\hline $\begin{array}{l}\text { The string removal task is a a valuable training exercise (Bài tập lấy bỏ các vòng xâu } \\
\text { là huấn luyện có giá trị) }\end{array}$ & 0 & 0 & 0 & $42(5)$ & $58(7)$ & $4.6 \pm 0.51$ \\
\hline $\begin{array}{l}\text { This model helps to develop basic injection fundamentals needed for FESS (Mô } \\
\text { hình này giúp phát triển kỹ năng chích tê cơ bản cần thiết cho phẫu thuật nội soi } \\
\text { chức năng xoang) }\end{array}$ & 0 & 0 & 0 & $25(3)$ & $75(9)$ & $4.8 \pm 0.45$ \\
\hline $\begin{array}{l}\text { The basic injection task is a valuable training exercise (Bài tập chích tê cơ bản là } \\
\text { huấn luyện có giá trị) }\end{array}$ & 0 & 0 & 0 & $33(4)$ & $67(8)$ & $4.7 \pm 0.49$ \\
\hline $\begin{array}{l}\text { This model helps develop dexterity, accuracy, and precision with sinus instruments } \\
\text { (bead task) (Mô hình này giúp phát triển độ khéo léo, chính xác khi sử dụng dụng } \\
\text { cụ phẫu thuật xoang (bài tập với hạt) }\end{array}$ & 0 & 0 & 0 & $25(3)$ & $75(9)$ & $4.8 \pm 0.45$ \\
\hline $\begin{array}{l}\text { The bead removal task is a valuable training exercise (Bài tập lấy bỏ hạt là huấn } \\
\text { luyện có giá trị) }\end{array}$ & 0 & 0 & 0 & $33(4)$ & $67(8)$ & $4.7 \pm 0.49$ \\
\hline $\begin{array}{l}\text { This model helps to develop fundamentals involved in maxillary antrostomy (Mô } \\
\text { hình này giúp phát triển kỹ năng cơ bản trong phẫu thuật mở lỗ thông xoang hàm) }\end{array}$ & 0 & 0 & $17(2)$ & $33(4)$ & $50(6)$ & $4.3 \pm 0.78$ \\
\hline $\begin{array}{l}\text { The maxillary antrostomy task is a valuable training exercise (Bài tập mở lỗ thông } \\
\text { xoang hàm là huấn luyện có giá trị) }\end{array}$ & 0 & 0 & $8(1)$ & $42(5)$ & $50(6)$ & $4.4 \pm 0.67$ \\
\hline $\begin{array}{l}\text { Use of this model will increase resident competency when used to train residents } \\
\text { prior to their first FESS (Tập luyện trước với mô hình này làm tăng khả năng của } \\
\text { bác sĩ nội trú trước khi thực hiện lần phẫu thuật nội soi chức năng xoang đầu tiên) }\end{array}$ & 0 & 0 & 0 & $25(3)$ & $75(9)$ & $4.8 \pm 0.45$ \\
\hline $\begin{array}{l}\text { This model is an adequate training model for future surgeons (Mô hình này là hình } \\
\text { thức luyện tập thích hợp cho các phẫu thuật viên tương lai) }\end{array}$ & 0 & 0 & 0 & $17(3)$ & $75(9)$ & $4.8 \pm 0.45$ \\
\hline $\begin{array}{l}\text { I would be interested in using this model to train residents (Tôi sẽ quan tâm sử dụng } \\
\text { mô hình này để huấn luyện cho các bác sĩ nội trú) }\end{array}$ & 0 & 0 & 0 & 0 & $100(12)$ & $5.0 \pm 0.00$ \\
\hline $\begin{array}{l}\text { This model correlates with the essential skills needed for FESS (Mô hình này có } \\
\text { tương quan với những kỹ năng cần thiết cho phẫu thuật nội soi chức năng xoang) }\end{array}$ & 0 & 0 & 0 & $17(3)$ & 75 (9) & $4.8 \pm 0.45$ \\
\hline $\begin{array}{l}\text { This model is able to mimic actual sinus anatomy (high fidelity model) (Mô hình } \\
\text { này giống với giải phẫu thật mũi xoang (độ tin cậy cao) }\end{array}$ & 0 & 0 & $33(4)$ & $42(6)$ & $17(2)$ & $3.8 \pm 0.72$ \\
\hline
\end{tabular}

\section{SD - standard deviation, FESS - functional endoscopic sinus surgery}

*Each Likert scale response is based on a 5-point scale response, strongly agree, agree, neutral, disagree, and strongly disagree corresponding with values 5, 4, 3, 2, 1 respectively. Responses are presented as a percentage. Mode response appears in bold for each statement. The last column represents the mean \pm standard deviation based on the Likert scale value, with maximum possible score 5. The survey was administered to participants with statements in both English and Vietnamese.

The overall response to the sinus surgery task trainer was immensely positive. Ninety two percent of participants showed strong interest in using the task trainer to train residents. 100\% agreed that the task trainer showed promise to simulating essential skills needed for functional endoscopic sinus surgery (FESS). 92\% felt it was an adequate training model. And $92 \%$ felt it would increase resident competency. These percentages are comparable to the same favorable scores reported by Steehler et al [6] and Malekzadeh et al [9] in their validity studies for US trainees. 
With our preliminary positive response from trainees in HCMC, we believe that surgical simulation stands not only to directly teach and transfer knowledge to otolaryngologists in training, but also answers the call for surgical capacity building in LMICs. There was immense enthusiasm for the surgical simulator by the surgical trainees who participated in the simulation. In fact, for many of the otolaryngology interns, it was their first time holding a sinus endoscope. During our multiple trips to Vietnam, we observed that the apprenticeship system in the operating room is not as robust as it may be in the United States. Some surgeries are broadcast to a classroom of trainees rather than having trainees in the operating room themselves. This may be even far more limited in more remote LMICs.

Surgical simulation can be used as a means to build up surgical capacity in low- and middle-income countries where resources are poor and the demand for hands-on training is high.
While it is not our intention to impose a Western educational system onto our Vietnamese colleagues, we believe that exposing and imparting various educational models such as surgical simulation will only open opportunities, especially with hands-on applications in surgical training. This aligns with global surgery's renewed mission for capacity building and knowledge transfer. The path to establishing trusting and respectful relationships to embark on collaborations like these takes time, listening, and compassion. Local collaboration and participation are critical [10]. For these authors, we found it fruitful establishing relationships with strong government-affiliated tertiary care hospital that have cooperation with surgeons and trainees invested in education. By sharing our knowledge and furthering education with each other, we can continue to expand capacity of the field of otolaryngology globally.

\footnotetext{
Acknowledgements: We would like to acknowledge Sonya Malekzadeh, MD and her group for sharing with us the si-
nus sugery trainer concept and design. We also acknowledge Resource Exchange International (REI).
Funding: This work was supported by the Einstein Global Health Center, Bronx, NY (3A7400 RS-GHC). The grant was
used to support purchasing simulation supplies and travel. The grant had no role in the study design, data collection,
data analysis, data interpretation, or manuscript creation.
Authorship contributions: AC: data collection, analysis, and interpretation of results, lead author of manuscript prepa-
ration and revisions. JF: data collection, manuscript revisions. JF: data collection, manuscript revisions. LT: data collec-
tion, manuscript revisions. BS: data collection, manuscript revisions. CY: study conception data collection, manuscript
revisions. All authors contributed to and approved the final manuscript.
Competing interests: The authors completed the ICMJE Disclosure of Interest form (available upon request from the
corresponding author), and declare no conflicts of interest study.
}

1 Christie SA, Nwomeh BC, Krishnaswami S, Yang GP, Holterman AL, Charles A, et al. Strengthening Surgery Strengthens Health Systems: A New Paradigm and Potential Pathway for Horizontal Development in Low- and Middle-Income Countries. World J Surg. 2019;43:736-43. Medline:30443662 doi:10.1007/s00268-018-4854-9

2 Butler MW. Developing pediatric surgery in low- and middle-income countries: An evaluation of contemporary education and care delivery models. Semin Pediatr Surg. 2016;25:43-50. Medline:26831137 doi:10.1053/j.sempedsurg.2015.09.008

3 Fuller JC, Justicz NS, Kim J, Cheney M, Castrillon R, Hadlock T. A Facial Plastic and Reconstructive Surgery Training Module Using Surgical Simulation for Capacity Building. J Surg Educ. 2019;76:274-80. Medline:30093333 doi:10.1016/j. jsurg.2018.06.027

4 Vyas RM, Sayadi LR, Bendit D, Hamdan US. Using Virtual Augmented Reality to Remotely Proctor Overseas Surgical Outreach: Building Long-Term International Capacity and Sustainability. Plast Reconstr Surg. 2020;146:622e-9e. Medline:33136961 doi:10.1097/PRS.0000000000007293

5 Parham G, Bing EG, Cuevas A, Fisher B, Skinner J, Mwanahamuntu M, et al. Creating a low-cost virtual reality surgical simulation to increase surgical oncology capacity and capability. Ecancermedicalscience. 2019;13:910. Medline:31123493 doi:10.3332/ecancer.2019.910

6 Steehler MK, Pfisterer MJ, Na H, Hesham H, Pehlivanova M, Malekzadeh S. Face, content, and construct validity of a low-cost sinus surgery task trainer. Otolaryngol Head Neck Surg. 2012;146:504-9. Medline:22114312 doi:10.1177/0194599811430187

7 Musbahi O, Aydin A, Al Omran Y, Skilbeck CJ, Ahmed K. Current Status of Simulation in Otolaryngology: A Systematic Review. J Surg Educ. 2017;74:203-15. Medline:27839694 doi:10.1016/j.jsurg.2016.09.007

8 Hasan O, Ayaz A, Jessar M, Docherty C, Hashmi P. The need for simulation in surgical education in developing countries. The wind of change. Review article. J Pak Med Assoc. 2019;69 Suppl 1:S62-8. Medline:30697022 
9 Malekzadeh S, Pfisterer MJ, Wilson B, Na H, Steehler M. A novel low-cost sinus surgery task trainer. Otolaryngol Head Neck Surg. 2011;145:530-3. Medline:21690274 doi:10.1177/0194599811413373

10 Stone GS, Olson KR. The Ethics of Medical Volunteerism. Med Clin North Am. 2016;100:237-46. Medline:26900110 doi:10.1016/j.mcna.2015.09.001

\section{Correspondence to:}

Angela Cao, M.D.

3400 Bainbridge Avenue, 3rd Floor

Bronx, NY 10467

USA

acao@montefiore.org 